in 1930-31. A map of the numerous discoveries accompanies a paper by Sir Douglas Mawson in the Geographical Journal for August. Mawson's map extends from about long. $45^{\circ} \mathrm{E}$. to long. $75^{\circ} \mathrm{E}$. Along almost the whole of that extent the coast line is now charted, and a number of prominent peaks have been fixed. During roughly the same period the Norwegian vessel Norvegia was in the same waters. Their map with less detail is published in a paper by Major G. Isachsen in Norges Svalbavd og Ishavsundersökelser, Meddelse Nr. 12. The two maps overlap east of Enderby Land and the names are different. There was, however, an agreement between the two explorers, Sir Douglas Mawson and Captain RiiserLarsen, made in a meeting in antarctic seas, to regard the meridian of long. $45^{\circ}$ E. as roughly dividing their respective spheres of work. The Discovery thus limited her work towards the west. It is to be hoped that the confusion of two sets of new names will not be perpetuated.

\section{Scientific Investigations in East Greenland}

GooD progress is reported in the Danish three-year programme of scientific investigations in East Green. land, which began last year under the direction of Dr. Lauge Koch. The entire expedition comprised 96 members and they had at their disposal two ships, twelve motor-boats and two aeroplanes. Twenty-six members of the expedition are spending the winter in Greenland: the others returned to Copenhagen on Feb. 19. According to the Times of Sept. 21 Dr. Koch announces that already 240,000 square kilometres of the east coast lands between lat. $70^{\circ}$ and $77^{\circ} \mathrm{N}$. have been surveyed largely with the help of aeroplanes. Important geological investigations have been carried on around King Oscar and Franz Josef fjords. During the coming winter the chief bases are to be at Scoresby Sound, Ella Island, Clavering Island and Hochstetter Sound. Each station will be provided with wireless and will serve as a base for seaplane flights as well as ground survey parties. Hydrographical investigations were also carried out in coastal waters and will be continued next summer. Biologists are attached to each field party.

\section{Relevelling of London}

THE adoption of the Newlyn datum for Ordnance levels in place of the old Liverpool datum involved a change in levels on the Ordnance maps throughout Great Britain. The difference, however, is not constant owing to errors due to imperfections of instruments in the past. In certain areas surface movements may also be responsible. A network of relevelling along twenty-one lines was completed for the London area in March 1932, involving about 2400 bench marks between Hemel Hempstead and Ware on the north, Godstone on the south, Windsor on the west, and Stroud and Chelmsford on the east. The new heights, as well as the old, with the location of the bench marks, are published in advance of the sheets involved in a volume entitled "Relevelling of London, $\mathrm{Ab}$. stracts of Secondary Lines" (Ordnance Survey 1932, 7s. 6d.) The difference between the old and new levels appears generally to be about a foot or a little more, the now levels showing the reduction.

\section{Aerial Photography in Map-making}

THe progress made of late years in topographical surveying by means of aerial photography is strikingly illustrated by a recent report from the Canadian Department of the Interior. The Dominion of Canada with its vast expanse of hyperborean territory, the accessibility of which is rendered extremely difficult by the physical conditions, has proved a splendid field for this modern method of planimetry. Within the last decade, a total area of 402,500 sq. miles has been covered by aerial photography, comprising $125,000 \mathrm{sq}$. miles by vertical photographs and 277,500 sq. miles by oblique photographs. Vertical photographs are serviceable for mapping to fairly large scales, or in districts where the country is rough and mountainous, while oblique photographs are more particularly adapted to the exploratory mapping of extensive areas of forest and lakeland of fairly uniform level, such as constitute so large a proportion of northern Canada. Indeed, the oblique method is known as the Canadian method and has been adopted in other countries where the conditions are similar. Its moderate cost, flexibility and the small amount of ground surveying required render it particularly applicable to northern latitudes. During the last ten years, forty map sheets on a scale of four miles to the inch, each covering an area of 5,000-6,500 sq. miles, and three map sheets on a scale of eight miles to the inch, each covering an area roughly four times as great as the 4 mile-inch maps, have been compiled from oblique photographs and published in a National Topographic Series designed to cover eventually the entire area of Canada. Other map sheets have been issued which have been compiled from vertical photographs on larger scales of 1 or 2 miles to the inch.

\section{The Worker's Point of View}

THE Human Factor, vol. 6 No. 8, contains an article by Mr. Louis Katin, a non-apprenticed workman, on "Craft Distinction in the Factory". $\mathrm{He}$ demonstrates the importance within the factory of the 'class-feeling' arising over apprenticeship. $\mathrm{He}$ explains the worker's prejudice against non-apprenticed companions as due to pride of craft, collective desire to produce better work than any other factory, and consequent dislike of anyone likely to lower general efficiency. $\mathrm{He}$ suggests that apprenticeship should be compulsory for all boys leaving schoo, and possible, without indentures, for those already in the industry. The employer should then make sure that each was taught by a skilled foreman. He cites as difficulties parental disapproval, the length of time involved, and the trade union and employer agreements which unduly limit the number of apprentices in some trades. Yet he thinks that the three parties concerned, consulting with the young people, should find a solution, and with the facilities now afforded by the technical schools the term of apprenticeship might be shortened. Mr. Katin deals convincingly with apprenticeship as a source of disharmony and

$$
\text { No. 3284, VoL. 130] }
$$

